DOI: https://doi.org/10.24127/ajpm.v9i2.2744

\title{
KEMAMPUAN LITERASI MATEMATIKA MENGGUNAKAN BAR MODEL PADA MATERI ALJABAR
}

\section{Agustiani Putri $^{{ }^{*}}$, Dadan Sumardani ${ }^{2}$, Wardani Rahayu ${ }^{3}$, Mimi Nur Hajizah ${ }^{4}$, Adi Rahman ${ }^{5}$}

\author{
1,2,3,4,5 Universitas Negeri Jakarta, Jakarta, Indonesia \\ * Corresponding author. \\ E-mail: $\quad$ agustianiputri15@gmail.com $^{\left.{ }^{*}\right)}$
}

Received 08 April 2020; Received in revised form 14 June 2020; Accepted 21 June 2020

\begin{abstract}
Abstrak
Penelitian ini bertujuan untuk mengetahui efektivitas penggunaan bar model terhadap kemampuan literasi matematika khususnya pada materi aljabar. Penelitian ini adalah penelitian kuantitatif. Metode penelitian yang digunakan adalah metode eksperimen dengan teknik pengambilan sampel menggunakan cluster sampling. Subjek dalam penelitian ini adalah 36 siswa pada kelas eksperimen dan kontrol. Kedua kelas yang dipilih berasal dari populasi yang berdistribusi normal, memiliki varians homogen dan mempunyai kesamaan rata-rata. Pengumpulan data menggunakan tes tertulis yang dibuat sesuai indikator keterampilan literasi matematika pada materi aljabar sebanyak 5 soal yang telah melalui uji validitas dan reliabilitas. Berdasarkan hasil penelitian, kelas eksperimen dan kelas kontrol berdistribusi normal dan memiliki varians yang sama. Pengujian hipotesis dilakukan dengan uji-t dan taraf signifikansi $\alpha=0,05$. Berdasarkan hasil post-test, diperoleh $t_{\text {hitung }}=4,38$ dan $t_{\text {tabel }}=1,67$ sehingga $t_{\text {hitung }}>t_{\text {tabel }}$, maka $H_{0}$ ditolak. Oleh karena itu, dapat disimpulkan bahwa penggunaan bar model lebih efektif daripada model konvensional untuk mengembangkan kemampuan literasi matematika.
\end{abstract}

Kata kunci: Aljabar; bar model; kemampuan literasi matematika.

\begin{abstract}
This study discusses the efectiveness of bar modeling on specific mathematical literacy abilities in algebraic material. This research is quantitative research. The research method used is a research method with a sampling technique using cluster sampling. The subjects in this study were 36 students in the experimental and control class. The second class chosen is normally distributed, has homogeneous variants and has the same average ability. Collecting data using written tests that are made in accordance with mathematical literacy skills in algebraic material as many as 5 questions that have been tested for validity and reliability. Based on the results of the study, the experimental class and the control class were normally distributed and had the same variants. Hypothesis testing is done by t-test and significance level $\alpha=0.05$. Based on the results of the calculation, obtained $t_{\text {count }}=4,38$ and $t_{\text {table }}=$ 1,67 so $t_{\text {count }}>t_{\text {table }}$, then $H_{0}$ is rejected. Therefore, it can be concluded that the use of bar models is more effective than conventional models for developing mathematical literacy skill.
\end{abstract}

Keywords: Algebra; bar modeling; mathematical literacy skill.

\section{PENDAHULUAN}

Literasi matematika adalah salah satu keterampilan yang perlu dikuasai siswa pada abad 21 karena merupakan perimbangan antara matematika dengan dan tanpa angka. Literasi matematika dapat membantu siswa untuk membaca informasi, mengidentifikasi, memahami masalah dan membuat suatu keputusan dengan metode penyelesaian yang tepat (Salsabila, Rahayu, Kharis, \& Putri, 2019). Namun kenyataannya adalah kemampuan literasi matematika siswa Indonesia masih tergolong rendah. Pada tahun 2012, rata-ratanya mencapai 375 dan berada di bawah rata-rata dari skala internasional yaitu 500. Dari 66 negara peserta Indonesia menduduki urutan ke- 
65 yang persentase literasi matematika pada level 1-2 mencapai angka 75,7\% sedangkan level 5-6 hanya mencapai $0,3 \%$ (Putri, Sumardani, Rahayu, \& Hajizah, 2020).

Penilaian tersebut sejalan dengan hasil dari penelitian sebelumnya yang menyatakan bahwa siswa belum dapat mengerjakan soal-soal yang non-rutin (Sumardani, Saraswati, Putri, Bakri, \& Muliyati, 2020), dan meskipun memuat indikator soal-soal yang sama (Bakri, Sumardani, \& Muliyati, 2019). Contohnya menyederhanakan ekspresi aljabar, siswa bisa menjawab benar soal rutin $4 a+3 b-a+b-1$. Namun, ketika diberikan soal non-rutin, seperti $3+a$, $2 x+4 y$ dan $3 a x 2 b$, siswa menjawab salah dan tidak dapat mengemukakan alasannya (Syawahid, 2019). Hal ini sebagai bukti bahwa siswa belum dapat memahami sepenuhnya operasi bentuk aljabar, terutama apabila soal disajikan dalam bentuk soal cerita.

Banyak penelitian yang dilakukan untuk mengetahui kesulitan siswa dalam literasi matematika. Kesulitan siswa terletak pada memahami soal (38\%), kesulitan transformasi (42\%), kesalahan pemodelan matematika (17\%), dan juga kesalahan pengkodean (3\%) (Wijaya, van den Heuvel-Panhuizen, Doorman, \& Robitzsch, 2014). Penelitian lain juga menyatakan bahwa siswa mengalami kesulitan merumuskan masalah dalam kehidupan sehari-hari ke dalam bentuk model matematika (Sumardani, Putri, \& Sumardani, 2020). Oleh karena itu, siswa perlu model pembelajaran yang tepat yaitu Bar Model.

Bar Model digunakan sebagai alat untuk membuat model dari masalah matematis karena dapat memvisualisasi sesuatu yang abstrak ke dalam bentuk gambar dengan menggunakan blok-blok berbetuk persegi panjang karena mudah dibagi, dan dapat digunakan sebelum siswa mengetahui solusi secara aljabar (Ramasamy \& Puteh, 2019). Bar Model dapat menjadi strategi alternatif yang membantu dalam menjembatani transisi yang sulit dari soal-soal cerita ke dalam ekspresi matematika (Gani, Tengah, \& Said, 2019).

Ada dua jenis bentuk dalam Bar Model yaitu berbentuk himpunan dan perbandingan (Yeap, 2014). Dalam model himpunan terdapat dua atau lebih himpunan bagian yang membentuk satu set (keseluruhan). Dalam Bar Model, balok persegi panjang mewakili jumlah yang membentuk 'bagian' seperti yang diilustrasikan dalam Gambar 1.

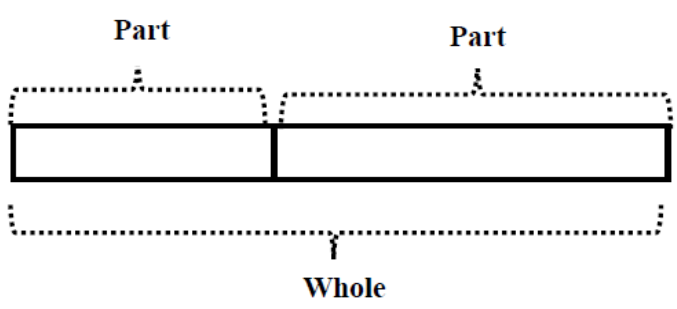

Gambar 1. Model himpunan.

Ada dua jenis bentuk perbandingan yaitu aditif dan multiplikasi. Dalam perbandingan aditif (Gambar 2a), satu kuantitas adalah jumlah tertentu dapat lebih atau kurang dari kuantitas lain. Perbandingan multiplikasi (Gambar 2b), satu kuantitas adalah jumlah tertentu kali dari kuantitas lain.

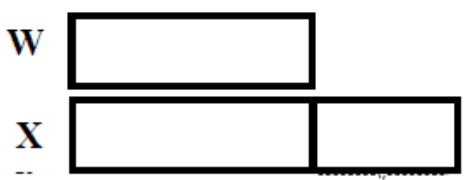

(a)

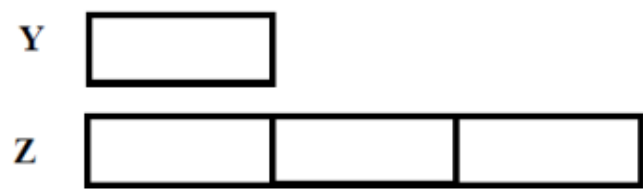

(b)

Gambar 2. Model aditif (a) dan multiplikasi (b) 
Penelitian sebelumnya juga telah menggunakan Bar Model untuk HOTS (Ramasamy \& Puteh, 2019), pemecahan masalah (Gani et al., 2019), dan menyelesaikan soal-soal yang berbentuk cerita (Morin, Watson, Hester, \& Raver, 2017). Namun, penggunaan Bar Model untuk kemampuan literasi matematika belum terdapat penelitiannya. Literasi matematika masih terdapat kekurangan pada materi aljabar karena siswa masih kesulitan pada soal non-rutin dan soal cerita, lemahnya gagasan pendukung dan pemodelan matematika (Mujulifah, Sugiatno, \& Hamdani, 2015).

Berdasarkan permasalahan di atas, penelitian ini diharapkan dapat menguji efektivitas dari penggunaan Bar Model terhadap kemampuan literasi matematik siswa pada materi aljabar di SMPN 74 Jakarta Timur.

\section{METODE PENELITIAN}

Penelitian ini dilakukan di SMPN 74 Jakarta. Penelitian ini melibatkan siswa di SMPN 74 Jakarta Timur kelas VII semester gasal. Waktu penelitian dari 10 Juli sampai 20 November 2019. Penelitian ini berlangsung 8 pertemuan dengan 6 pertemuan untuk menerapkan bar model di kelas eksperimen dan 2 pertemuan lagi untuk pre-test dan posttest kemampuan literasi matematika siswa kedua kelas sebelum dan setelah diberi perlakuan.

Jumlah siswa pada kelas kontrol terdapat 36 orang dan kelas eksperimen ada 36 orang. Kemampuan literasi matematika siswa dilakukan pada pokok bahasan aljabar. Penelitian ini terdiri dari kelas kontrol dan eksperimen. Kelas VII A sebagai kelas eksperimen yang menggunakan bar model dan kelas VII B sebagai kelas kontrol yang tanpa diberikan perlakuan.

Penelitian ini adalah kuantitatif yang di dalamnya terdapat analisis dan penarikan kesimpulan yang diperoleh dari hasil pengujian data. Metode yang digunakan dalam penelitian ini adalah eksperimen semu, karena penelitian ini tidak memungkinkan untuk mengontrol sepenuhnya terhadap variabel-variabel luar yang dapat mempengaruhi dalam pelaksanaan eksperimen.

Kemampuan literasi matematika siswa dapat diukur melalui instrumen tes berupa 5 soal berbentuk uraian pada materi aljabar yang sudah disesuaikan dengan indikator literasi matematika. Pre-test dan post-test diberikan kepada siswa untuk mengetahui kemampuan literasi matematika siswa sebelum dan setelah diberikan perlakuan. Sebelum instrumennya digunakan, dilakukan uji validitas oleh ahli dan juga empiris, dan diujicobakan pada kelas yang bukan eksperimen.

Kelompok penelitian terbagi dua yaitu kelas eksperimen menggunakan bar model dan kelas kontrol yang diajar tanpa adanya sebuah perlakuan. Desain penelitian ini dapat digambarkan Pada Tabel 1.

Tabel 1. Desain Penelitian

\begin{tabular}{cccc}
\hline Kelas & Pre-test & Perlakuan & Post-test \\
\hline $\mathrm{E}$ & $\mathrm{O}_{1}$ & $\mathrm{X}$ & $\mathrm{O}_{2}$ \\
$\mathrm{~K}$ & $\mathrm{O}_{3}$ & & $\mathrm{O}_{4}$ \\
\hline
\end{tabular}

Keterangan:

$\mathrm{E}=$ Kelas eksperimen

$\mathrm{K}=$ Kelas kontrol

$\mathrm{O}_{1}=$ Pre-test pada kelas eksperimen

$\mathrm{O}_{2}=$ Post-test pada kelas eksperimen

$\mathrm{O}_{3}=$ Pre-test pada kelas kontrol

$\mathrm{O}_{4}=$ Post-test pada kelas kontrol

$\mathrm{X}=$ Perlakuan dengan bar model

Populasi penelitian adalah seluruh siswa kelas VII di SMPN 74 Jakarta Timur yang terdaftar pada semester gasal 2018/2019. Pengambilan sampel pada penelitian ini menggunakan teknik 
cluster sampling yaitu kelas VII A, VII B dan VII C.

Selanjutnya, untuk mengetahui keadaan awal kelas sebelum dijadikan sampel dilakukan uji prasyarat analisis pada ketiga kelas tersebut, yaitu uji normalitas, homogenitas dan kesamaan rata-rata yang menggunakan data hasil ulangan tengah semester. Setelah itu, terpilih dua kelas dengan kemampuan awal yang sama untuk dijadikan sebagai sampel penelitian, kemudian ditentukan kelas eksperimen yang belajar dengan bar model dan kelas kontrol.

Data yang diperoleh penelitian ini merupakan hasil tes kemampuan literasi matematika siswa sebelum dan sesudah penelitian yang mengacu pada indikator PISA yaitu komunikasi, representasi, penalaran dan argumentasi, merancang strategi untuk menyelesaikan masalah, penggunaan simbol, bahasa formal dan teknis, penggunaan operasi matematika. Tes yang sama diberikan pada kedua kelas yang berupa soal-soal uraian.

Teknik analisis data dilakukan pada sebelum dan setelah perlakuan. Tahap pengujian sebelum perlakuan yaitu uji normalitas, homogenitas, dan kesamaan rata-rata. Sedangkan tahapan setelah perlakuan yaitu uji normalitas, homogenitas, dan uji t.

Uji normalitas yang digunakan sebelum dan setelah perlakuan adalah uji Lilliefors dengan $\alpha=0,05$. Kriteria yang digunakan dalam uji ini adalah $L_{0}>L_{\text {tabel }}$ maka $H_{0}$ ditolak, berarti sampel yang digunakan pada penelitian ini berasal dari populasi yang tidak berdistribusi normal.

Uji homogenitas yang dilakukan sebelum perlakuan untuk mengetahui kelas yang berasal dari populasi yang homogen atau tidak. Sampel pada uji homogenitas berasal dari populasi yang berdistribusi normal. Uji homogenitas dilakukan dengan uji Bartlett dengan $\alpha$
$=0,05$. Kriteria dalam pengujian yaitu tolak $H_{0}$ jika $\chi^{2} \geq \chi_{(1-\alpha)(k-1)}$ dengan peluang $(1-\alpha)$ dan $d k=(k-1)$.

Uji homogenitas yang dilakukan setelah perlakuan adalah menggunakan uji Fisher dengan taraf signifikan $\alpha=0,05$. Data yang digunakan adalah hasil tes kemampuan berpikir kritis matematis siswa pada pokok bahasan integral. Uji ini tak hanya sebagai uji prasyarat, namun juga sebagai penentu statistik uji-t yang digunakan untuk menguji hipotesis.

Pengujian hasil kesamaan ratarata dilakukan sebelum perlakuan untuk mengetahui kondisi awal rata-rata kelas sebelum perlakuan. Uji kesamaan ratarata dalam penelitian ini menggunakan uji analisis varians satu arah dengan $\alpha=$ 0,05 . Kriteria dalam pengujian ini yaitu $F_{\text {hitung }}>F_{\text {tabel }}$ maka $H_{0}$ ditolak yang berarti bahwa terdapat perbedaan ratarata pada ketiga kelas. Oleh karena itu, dilakukan uji lanjutan dengan uji Tukey.

Pengujian hipotesis ini bertujuan untuk mengetahui apakah kemampuan berpikir kritis matematis menggunakan model generative learning lebih tinggi daripada menggunakan model CORE. Pengujian hipotesis ini menggunakan statistik uji $t$, dimana $\sigma_{1}^{2}=\sigma_{2}^{2}$ dengan taraf signifikan $\alpha=0,05$. Kriteria pada pengujian yang digunakan yaitu Jika $t_{\text {hitung }}>t_{\text {tabel }}$, maka $H_{0}$ ditolak.

\section{HASIL DAN PEMBAHASAN}

Sebelum dilakukannya penelitian terkait kemampuan literasi matematika, maka diperoleh hasil uji prasyarat.

\section{Uji Normalitas Sebelum Perlakuan}

Uji normalitas menggunakan uji Lilliefors dengan $\alpha=0,05$. Data yang digunakan adalah hasil nilai pre-test kemampuan literasi matematika siswa kelas VII A, VII B, dan VII C pada materi aljabar. Kriteria yang digunakan 
dalam uji ini adalah $L_{0}>L_{\text {tabel }}$ maka $H_{0}$ ditolak, yang berarti sampel yang digunakan pada penelitian ini berasal dari populasi yang tidak berdistribusi normal. Berikut ini merupakan hasil pengujian uji normalitas ketiga kelas sebelum diberi perlakuan menggunakan uji Lilliefors dapat dilihat pada tabel 2.

Tabel 2. Uji normalitas sebelum perlakuan

\begin{tabular}{ccc}
\hline Kelas & $\boldsymbol{L}_{\mathbf{0}}$ & $\boldsymbol{L}_{\text {tabel }}$ \\
\hline VII A & 0,127 & 0,227 \\
VII B & 0,106 & 0,227 \\
VII C & 0,110 & 0,227 \\
\hline
\end{tabular}

Berdasarkan pada Tabel 2, secara keseluruhan dari ketiga kelas tersebut memiliki $L_{0}<L_{\text {tabel }}$, maka diperoleh sebuah kesimpulan bahwa ketiga kelas berdistribusi normal.

\section{Uji Homogenitas Sebelum Perlakuan}

Uji homogenitas yang dilakukan untuk mengetahui kelas berasal dari populasi yang homogen atau tidak. Sampel pada uji homogenitas berasal dari populasi yang telah berdistribusi normal. Uji homogenitas dilakukan menggunakan uji Bartlett dengan $\alpha=$ 0,05 . Kriteria pada pengujian yaitu tolak $H_{0} \quad$ ketika $\chi^{2} \geq \chi_{(1-\alpha)(k-1)}$ dengan peluang $(1-\alpha)$ dan $d k=(k-1)$.

Berdasarkan uji homogenitas, diperoleh $\chi_{\text {hitung }}^{2}=0,078$ dan $\chi_{\text {tabel }}^{2}=$ 5 ,992. Dengan demikian, disimpulkan $\chi_{\text {hitung }}^{2}<\chi_{\text {tabel }}^{2}$ maka $H_{0}$ diterima atau ketiga kelas tersebut memiliki varians sama atau homogen.

\section{Uji Analisis Kesamaan Rata-rata}

Pengujian pada hasil kesamaan rata-rata dilakukan untuk mengetahui kondisi awal rata-rata kelas sebelum perlakuan. Uji kesamaan rata-rata dalam penelitian ini menggunakan uji analisis varians satu arah dengan $\alpha=0,05$.
Berdasarkan hasil perhitungan anava, diperoleh nilai $F_{\text {hitung }}=3,654$ dan $F_{\text {tabel }}=3,079$. Dengan demikian, dapat disimpulkan bahwa $F_{\text {hitung }}>$ $F_{\text {tabel }}$ maka $H_{0}$ ditolak yang berarti bahwa terdapat perbedaan rata-rata pada ketiga kelas. Oleh karena itu, dilakukan uji lanjutan dengan uji Tukey (Tabel 3)

Tabel 3. Uji lanjutan Tukey.

\begin{tabular}{ccc}
\hline Kelas & $\boldsymbol{Q}_{\text {hitung }}$ & $\boldsymbol{Q}_{\text {tabel }}$ \\
\hline A vs B & 4,326 & 5,856 \\
A vs C & 6,508 & 5,856 \\
B vs C & 1,891 & 5,856 \\
\hline
\end{tabular}

Berdasarkan pada Tabel 3, dapat terlihat bahwa terdapat dua pasang kelas yang hasil $Q_{\text {hitung }}<Q_{\text {tabel }}$, sehingga tidak memiliki perbedaan rata-rata yaitu kelas VII A dan VII B, serta kelas VII B dan VII C. Selain itu, satu pasang kelas memiliki $Q_{\text {hitung }}>Q_{\text {tabel }}$, sehingga memiliki perbedaan rata-rata yaitu kelas VII A dan VII C. Oleh karena itu, yang dipilih kelas VII A dan VII B sebagai sampel penelitian ini karena kedua kelas memiliki kemampuan yang sama.

\section{Uji Normalitas Setelah Perlakuan}

Uji normalitas setelah perlakuan menggunakan uji Lilliefors dengan taraf signifikannya $\alpha=0,05$. Data yang diuji adalah hasil nilai post-test kemampuan literasi matematika siswa kelas kontrol dan eksperimen pada pokok bahasan aljabar. Kriteria yang digunakan uji ini adalah $L_{0}>L_{\text {tabel }}$ maka $H_{0}$ ditolak, berarti sampel yang digunakan dalam penelitian ini berasal dari populasi yang tidak berdistribusi normal. Hasil pengujian normalitas kedua kelas setelah diberikan perlakuan disajikan pada Tabel 4.

Berdasarkan perhitungan Tabel 4, diketahui bahwa kedua kelas memiliki perhitungan $L_{0}<L_{\text {tabel }}$, keputusannya $H_{0}$ diterima. Hal ini dapat disimpulkan 
DOI: https://doi.org/10.24127/ajpm.v9i2.2744

kelas VII A sebagai kelas eksperimen dan kelas VII B sebagai kelas kontrol berasal dari populasi yang berdistribusi normal.

Tabel 4. Hasil uji normalitas setelah perlakuan.

\begin{tabular}{ccc}
\hline Kelas & $\boldsymbol{L}_{\mathbf{0}}$ & $\boldsymbol{L}_{\text {tabel }}$ \\
\hline VII A & 0,127 & 0,227 \\
VII B & 0,115 & 0,227 \\
\hline
\end{tabular}

\section{Uji Homogenitas Setelah Perlakuan}

Uji homogenitas setelah perlakuan menggunakan uji Fisher dengan taraf signifikan $\alpha=0,05$. Data yang diuji adalah hasil nilai post-test kemampuan literasi matematika siswa pada kedua kelas pada materi aljabar. Uji ini tidak hanya sebagai uji prasyarat, namun juga digunakan sebagai penentu statistik uji- $t$ mana yang akan digunakan.

Berdasarkan dari hasil pengujian homogenitas dengan $F_{\left(1-\frac{\alpha}{2}\right) ;\left(n_{1}-1, n_{2}-1\right)}$ $\leq F_{\text {hitung }} \leq F_{\frac{\alpha}{2}\left(n_{1}-1, n_{2}-1\right)}$ yaitu 0.510 $\leq 1.040 \leq 1.961$ maka $H_{0}$ diterima. Oleh karena itu, disimpulkan bahwa data dari hasil tes kemampuan berpikir kritis matematis siswa di kelas eksperimen I dan juga kelas eksperimen II memiliki varians yang sama. Selanjutnya untuk menguji hipotesis menggunakan uji-t.

\section{Pengujian Hipotesis}

Pengujian hipotesis ini bertujuan untuk mengetahui adanya perbedaan pada kemampuan literasi matematika siswa yang belajar di kelas eksperimen dan kontrol pada pokok bahasan aljabar. Pengujian ini dilakukan pada sebelum dan sesudah adanya perlakuan pada kelas eksperimen. Pengujian hipotesis juga dilakukan dengan menggunakan statistik uji- $t$ dengan taraf signifikan $\alpha=0,05$. Kriterianya adalah $t_{\text {hitung }}>$ $t_{\text {tabel }}$, maka $H_{0}$ ditolak. Hal ini menyatakan bahwa ada perbedaan di antara kedua kelompok yang diuji baik pada kelas eksperimen dan kontrol baik setelah melakukan pre-test dan maupun post-test. Hasil pengujian dapat dilihat pada Tabel 5.

Tabel 5. Hasil pengujian hipotesis sebelum dan setelah perlakuan.

\begin{tabular}{cccccc}
\hline Kelompok & Tes & $\mathbf{N}$ & Rata-rata & $\begin{array}{c}\text { Standar } \\
\text { Deviasi }\end{array}$ & 't' value \\
\hline Eksperimen & Pre-test & 36 & 76,38 & 16,17 & 0,45 \\
Kontrol & Pre-test & 36 & 75,82 & 16,73 & \\
Eksperimen & Post-test & 36 & 76,38 & 16,17 & 4,49 \\
& Pre-test & 36 & 75,82 & 15,73 & \\
Kontrol & Post-test & 36 & 78,96 & 16,73 & 4,56 \\
Eksperimen & Post-test & 36 & 89,54 & 18,01 & \\
Kontrol & 36 & 78,96 & 18,73 & 4,38 \\
\hline
\end{tabular}

Rata-rata skor pre-test siswa pada kelas eksperimen dan kontrol masingmasing adalah 76,38 dan 75,82 . Nilai $t_{\text {hitung }}=0,45<t_{\text {tabel }}=1,67$ dengan taraf $\alpha=0,05$, maka $H_{0}$ diterima. Oleh karena itu, dapat disimpulkan bahwa kemampuan literasi matematika siswa pada kelas kontrol dan eksperimen tidak berbeda secara signifikan dalam nilai pre-test yang diberikan.

Rata-rata nilai pre-test dan posttest siswa pada kelompok eksperimen 
masing-masing adalah 76,38 dan 89,54. Pada tabel 5 menunjukkan bahwa nilai $t_{\text {hitung }}=4,49>t_{\text {tabel }}=1,67$ yang menggunakan taraf $\alpha=0,05$ maka $H_{0}$ ditolak. Hal ini menunjukkan bahwa ada perbedaan yang signifikan antara pretest dan post-test siswa yang diajarkan menggunakan bar model.

Rata-rata nilai pre-test dan posttest siswa pada kelas kontrol masingmasing adalah 75,82 dan 78,96. Pada Tabel 5 menunjukkan nilai $t_{\text {hitung }}=$ $4,56>t_{\text {tabel }}=1,67$ yang menggunakan taraf $\alpha=0,05$, yang berarti $H_{0}$ ditolak. Hal ini menunjukkan bahwa ada perbedaan yang signifikan antara pretest dan post-test siswa yang diajarkan menggunakan model konvensional.

Rata-rata nilai dari post-test siswa pada kelas eksperimen dan kontrol masing-masing adalah 89,54 dan 78,96. Nilai $t_{\text {hitung }}=4,38>t_{\text {tabel }}=1,67$ menggunakan taraf $\alpha=0,05$, maka $H_{0}$ diterima. Oleh karena itu, disimpulkan bahwa kemampuan literasi matematika siswa di kelas eksperimen yang diajar dengan bar model lebih tinggi daripada kelas kontrol, sehingga ada perbedaan yang signifikan antara kelas eksperimen dengan kelas kontrol.

Bar model secara keseluruhan lebih efektif daripada konvensional. Hal ini dikarenakan bar model merupakan representasi pemodelan bentuk konkret yang proses belajarnya siswa melewati tiga tahap, yaitu: 1) tahap enactive: pada tahap ini siswa belajar secara langsung memanipulasi objek konkret pada soal cerita yang diberikan; 2) tahap iconic: siswa membayangkan kembali dengan memberikan gambaran tentang benda atau peristiwa yang dialami pada tahap enactive; 3) tahap symbolic: pada tahap ini siswa sudah mampu menggunakan notasi atau simbol tanpa ketergantungan terhadap objek riil (Koleza, 2015). Tiga tahapan tersebut dilibatkan ke dalam proses pembelajaran.

Langkah pertama proses literasi matematika menggunakan bar model adalah memahami situasi dari masalah yang diberikan untuk dikonstruksi. Pada proses ini diterapkan tahap enactive, siswa dituntut untuk mengkonstruksikan masalah yang diberikan ke dalam model situasional. Pemahaman masalah yang baik diperlukan agar dapat memahami karakteristik masalah yang dihadapinya.

Langkah selanjutnya menyusun situasi dengan cara menentukan variabel yang ada dalam masalah tersebut. Tidak hanya itu, langkah ini juga menuntut proses penyederhanaan situasi dengan cara mendefinisikan masalah dengan tepat agar membantu dalam penyusunan model nyata dari situasi masalah yang ada. Pendefinisian masalah harus logis dan sesuai dengan konteksnya.

Setelah masalah disederhanakan dilakukan proses matematisasi masalah. Proses ini melibatkan tahap iconic yang merupakan pengubahan masalah nyata menjadi model matematikanya dengan menggunakan beberapa unit bar. Model matematikanya tersebut dapat memuat operasi dan variabel yang mewakili dari masalah yang telah dimodelkan. Siswa yang dapat melalui tahap iconic dengan baik dalam literasi matematika harus didukung model yang menjembatani fase konkret abstrak (Clement, 2017).

Langkah keempat adalah bekerja secara matematis. Hasil dari proses ini adalah solusi matematis yang kemudian akan ditafsirkan kedalam dunia nyata sebagai solusi nyata. Meskipun melalui proses menafsirkan telah diperoleh solusi sesuai dengan konteksnya, proses belum berhenti. Solusi tersebut perlu untuk divalidasi untuk melihat apakah diperlukan proses pemodelan ulang dengan melihat kesesuaian hasil dengan permasalahan, data serta teori. Setelah 
itu, dilanjutkan ke tahap terakhir yaitu menyajikan solusi akhir.

Langkah-langkah tersebut dapat memfasilitasi siswa di kelas eksperimen dalam mengembangkan kemampuan literasi matematika. Dengan langkahlangkah pembelajaran bar model ini, secara bertahap siswa dibimbing untuk memahami maksud dari soal, menjawab siapa dan apa saja yang terlibat dalam soal, menggambar atau membuat model matematis berdasarkan soal yang ada dan menyelesaikan soal tersebut dengan cara yang tepat dan menuliskan kalimat matematisnya. Berbeda halnya dengan kelas kontrol yang kurang menunjukkan pemahaman dan model matematisnya, serta tidak secara bertahap langsung ke ekspresi matematikanya.

Kelebihan dari bar model adalah representasi visual mudah dipelajari dari kuantitas dan hubungan antara kuantitas dalam memecahkan masalah, ditujukan kepada semua siswa terutama untuk siswa yang masih kurang berprestasi atau tingkat menengah, memecahkan masalah aritmatika yang melibatkan empat operasi bilangan bulat, desimal, pecahan, angka dan rasio, dan masalah persentase, memberikan jembatan dari aritmatika ke aljabar pada siswa belajar matematika. Kekurangan dari bar model yaitu tidak terlalu berlaku dalam materi geometri dan statistik dan menggambar panjang bagian yang berbeda dari bar persegi panjang bisa sulit.

Penelitian ini didukung dengan penelitian yang ada bahwa bar model merupakan metode yang sangat efektif untuk menyelesaikan masalah kompleks yang menggunakan diagram bergambar (Madani, 2018) Bar model juga efektif membantu merepresentasikan masalah dan menemukan solusi menggunakan model matematis (Mufliva \& Herman, 2016). Bar model juga membantu siswa dalam menyelesaikan soal matematika yang non rutin karena dibimbing secara terstruktur dan juga sistematis sehingga mampu mengembangkan kemampuan literasi siswa (Thirunavukkarasu \& Senthilnathan, 2017).

Hasil penelitian ini diharapkan mampu menjadi acuan bagi guru untuk menggunakan model pembelajaran yang tepat dalam meningkatkan kemampuan literasi matematika siswa yaitu dengan bar model. Selain itu, bar model juga dapat digunakan secara komprehensif kepada seluruh siswa tidak memandang latar belakang siswa tersebut. Penelitian ini juga diharapkan mampu memberikan gambaran terkait kemampuan literasi matematika di sekolah menengah yang dapat menjadi perhatian bagi sekolah untuk dikembangkan dalam pelajaran.

\section{KESIMPULAN DAN SARAN}

Berdasarkan hasil pengujian dan pembahasan, ada perbedaan signifikan kemampuan literasi matematika antara siswa di kelas kontrol dan eksperimen yang ditinjau dari nilai post-test dengan rata-rata yang lebih tinggi pada kelas eksperimen. Hal ini mengindikasikan bahwa efektivitas penggunaan dari bar model dalam pembelajaran lebih tinggi daripada kelas konvensional pada pokok bahasan aljabar kelas VII di SMPN 74 Jakarta Timur. Pada kelas eksperimen juga menunjukkan hasil post-test lebih tinggi rata-ratanya dari pre-test. Oleh karena itu, bar model lebih efektif dari pada model konvensional.

Berkenaan hasil penelitian yang diperoleh, maka saran untuk penelitian berikutnya adalah untuk menggunakan bar model pada tingkat kelas dan pokok bahasan yang berbeda. Selain itu, guru dapat menggunakan model ini dalam pembelajaran di kelas. 


\section{DAFTAR PUSTAKA}

Bakri, F., Sumardani, D., \& Muliyati, D. (2019). Integrating Augmented Reality into Worksheets: Unveil Learning to Support Higher-order Thinking Skills. AIP Conference Proceedings, 2169(November), 17. https://doi.org/10.1063/1.5132647

Clement, G. F. (2017). Exploring the Influence of the Singapore Modeling Method on Prospective Elementary Teachers in A University Mathematics Course. In $H A L$.

Gani, M. A., Tengah, K. A., \& Said, H. (2019). Bar Model as Intervention in Solving Word Problem of Percentage. International Journal on Emerging Mathematics Education, 3(1), 69.

Koleza, E. (2015). The Bar Model as A Visual Aid For Developing Complementary/Variation

Problems. Proceedings of the Ninth Congress of the European Society for Research in Mathematics Education, 19401946.

Madani. (2018). Using Bar Model to Solve Word Problems on Profit, Loss and Discount. Journal of Physics: Conf. Series 1097, 1-9.

Morin, L. L., Watson, S. M. R., Hester, P., \& Raver, S. (2017). The Use of a Bar Model Drawing to Teach Word Problem Solving to Students with Mathematics Difficulties. Learning Disability Quarterly, 40(2), 91-104.

Mufliva, R., \& Herman, T. (2016). Penggunaan Bar Model untuk Meningkatkan Kemampuan
Membuat Model Matematis dan Keterampilan Prosedural Serta Ketekunan Belajar Siswa Sekolah Dasar. Jurnal Penelitian Pendidikan UPI, 16(2), 147-159.

Mujulifah, F., Sugiatno, \& Hamdani. (2015). Literasi Matematis Siswa Dalam Menyederhanakan Ekspresi Aljabar. Jurnal Pendidikan Dan Pembelajaran Khatulistiwa, 4(1), 1-12.

Putri, A., Sumardani, D., Rahayu, W., \& Hajizah, M. N. (2020). Kemampuan Berpikir Kritis Matematis Menggunakan Model Generative Learning dan Connecting, Organizing, Reflecting, Extending (CORE). AKSIOMA: Jurnal Program Studi Pendidikan Matematika, 9(1), 108-117.

https://doi.org/10.24127/ajpm.v9i1. 2617

Ramasamy, R., \& Puteh, M. (2019). The Effectiveness of Bar Model to Enhance HOTs in Mathematics for Year 4 Pupils. International Journal of Academic Research in Progressive Education and Development, 8(1), 22-28.

Salsabila, E., Rahayu, W., Kharis, S. A., \& Putri, A. (2019). Analysis of Mathematical Literacy on Students' Metacognition in Conic Section Material. Journal of Physics: Conference Series, 1417(1), 1-8. https://doi.org/10.1088/17426596/1417/1/012057

Sumardani, D., Putri, A., \& Sumardani, N. I. (2020). E-Learning Utilizing Schoology: Teaching Theory of Relativity Using Online. Risenologi (Jurnal Sains, 
DOI: https://doi.org/10.24127/ajpm.v9i2.2744

Teknologi, Sosial, Pendidikan, Dan Bahasa), 5(1), 48-55.

Sumardani, D., Saraswati, R. R., Putri, A., Bakri, F., \& Muliyati, D. (2020). System Implementation of Augmented Reality Application in Student Worksheet. Informatika: Fakultas Sains Dan Teknologi Universitas Labuhanbatu, 8(1), 10-18.

Syawahid, M. (2019). Mathematical Literacy in Algebra Reasoning. International Journal of Insight for Mathematics Teaching, 02(1), 3346.

Thirunavukkarasu, M., \& Senthilnathan, S. (2017). Effectiveness of Bar Model in Teaching Algebra at Secondary Level. International Journal of Teacher Educational Research (IJTER), 6(10), 34-43.

Wijaya, A., van den Heuvel-Panhuizen, M., Doorman, M., \& Robitzsch, A. (2014). Difficulties in Solving Context-Based PISA mathematics tasks: An analysis of students' errors. The Mathematics Enthusiast, 11(3), 555-584.

Yeap. (2014). Bar Modelling-A Problem-solving Tool from Research to Practice: An Effective Singapore Math Strategy. Singapore: Marshall Cavendish Ed. 